\title{
STUDI PEMANFAATAN SERAT IJUK SEBAGAI BAHAN TAMBAH TERHADAP MUTU BATA BETON KARAWANG (ROSTER)
}

\author{
Ir. Erna Septiandini. MT dan Dede Sulaiman, S.Pd
}

\begin{abstract}
Abstrak
Penelitian ini bertujuan untuk mengetahui perbedaan mutu bata beton karawang (roster) yang menggunakan serat ijuk sebagai bahan tambah dengan persentase 2\%, 4\%, 6\% dan 8\% dari berat semen terhadap mutu BBK 10 bata beton karawang (roster) Standar Nasional Indonesia (SNI 03-15701989).Pelaksanaan kegiatan penelitian dilakukan di laboratorium Balai Bahan dan Barang Teknik Dinas Perindustrian dan Perdagangan Propinsi DKI Jakarta di Jl. Let.jen Suprapto Cempaka Putih, Jakarta. Pembuatan benda uji dilakukan di Pabrik buis beton Aneka Alam di Cipondoh Raya, Tangerang-Banten. Waktu Penelitian dilaksanakan dari bulan November - Januari 2005. Metode penelitian ini menggunakan metode eksperimen yang mengacu pada SNI 03-1570-1989. Jumlah benda uji seluruhnya ada 40 buah dari 4 perlakuan, masing-masing kelompok perlakuan ada 10 buah dengan perbandingan $1: 6$ dan serat ijuk sebesar 2\%, 4\%, 6\% dan 8\% terhadap berat semen, dengan perincian 5 buah untuk pengujan kuat tekan dan 5 buah untuk pengujian daya serap. Setiap benda uji akan dilakukan pengujan kuat tekan dan daya serap. Data yang diperoleh dianalisa dengan menggunakan analisa varians dan diuji $t$ rata-rata satu pihak dengan taraf signifikan $(\alpha)=0,01$. Hasil penelitian ini didapat bahwa penggunaan bahan tambah serat ijuk tidak dapat dijadikan sebagai bahan tambah pada pembuatan roster, dan tidak dapat menghasilkan mutu roster kelas BBK 10 menurut SNI 03-1570-1989.
\end{abstract}

\section{Pendahuluan}

Pembangunan fisik merupakan salah satu proses yang bertujuan untuk men-capai masyarakat adil dan makmur. Dalam melaksanakan pembangunan tersebut ten-tunya harus ditunjang oleh adanya industri bahan bangunan yang diproduksi dalam berbagai jenis dan dengan skala yang memadai. Untuk

mensukseskan rencana pembangunan fisik tersebut perlu adanya industri bahan bangunan yang menghasilkan produk yang bermutu baik dengan harga yang terjangkau. Penelitian dan pengembangan di bidang industri konstruksi dan 
industri bahan bangunan tidak saja perlu untuk mensukseskan program pembangunan fisik, tetapi juga untuk memperoleh pengurangan yang optimal harga bahan bangunan dan biaya konstruksi tanpa mengurangi mutu konstruksi dan kekuatan bangunan, serta keindahan arsitekturnya. Salah satu alternatif desain bahan bangunan baru yang mu-dah didapat dan murah harganya, yaitu dengan menggunakan bahan baku lokal atau bahan lain, seperti limbah perkebunan yang masih banyak kita jumpai di pedesaan.

Perkebunan yang jumlahnya cukup banyak terdapat di Indonesia salah satu-nya adalah perkebunan aren, dan salah satu bagian dari pohonnya adalah berupa ijuk. Umumnya ijuk sering kita jumpai dan dipergunakan untuk atap rumah, tambang, sapu dan untuk perlengkapan pembuatan taman. Menurut penelitian, penambahan serat ijuk pada pembuatan genteng beton dapat memperbaiki sifat fisis mekanis yang dimiliki, serta meningkatkan kekuatan lentur serta mengurangi sifat regasnya, karena hal ini didukung oleh sifat serat yang kokoh, keras dan lentur.

Pada umumnya limbah ijuk dapat digunakan sebagai bahan bangunan, seperti pada pembangunan tanggul atau dinding saluran pengairan, limbah ini digunakan sebagai penyaring air irigasi. Serat ijuk bersifat lentur dan tidak mudah rapuh, sangat tahan dalam genangan air yang asam termasuk genangan air laut yang mengandung garam. Walaupun demikian ijuk memiliki kelemahan yaitu tidak tahan terhadap api, jadi mudah terbakar.

Penggunaan ijuk sebagai bahan tambah pada campuran bata beton kara-wang (roster) masih belum pernah dilakukan. Berdasarkan kondisi tersebut perlu dilakukan penelitian mengenai pengaruh penambahan ijuk sebagai bahan campuran terhadap kekuatan bata beton karawang (roster). Banyak serat ijuk yang digunakan dalam penelitian ini ditentukan dalam persen terhadap berat semen Portland yaitu $2 \%, 4 \%, 6 \%$ dan $8 \%$ dengan panjang $3 \mathrm{~cm}$.

\section{Prosedur Penelitian}

1. Melakukan persiapan bahan dan alat untuk pembuatan benda uji.

2. Membuat Surat Keterangan untuk penelitian.

MENARA, JURNAL TEKNIK SIPIL VOL. I, NO. 1, JANUARI 2006 ;75-81 
3. Mengadakan pembuatan benda uji, perawatan benda uji dan pengujian benda uji.

4. Menghitung nilai kuat tekan dan penyerapan benda uji.

\section{Hasil Penelitian}

Berdasarkan hasil penelitian ini terdapat hubungan antara hasil pengujian kuat tekan dengan hasil pengujian penyerapan air roster, dimana adanya pengaruh dari jumlah persentasi bahan tambah yaitu serat ijuk terhadap hasil pengujian kuat tekan dan penyerapan air roster.

Semakin bertambahnya persentasi bahan tambah yaitu serat ijuk, maka semakin menurunnya kuat tekan yang didapat dan semakin meningkatnya nilai persentasi penyerapan air pada roster. Pernyataan tersebut dapat memberikan penjelasan bahwa hasil pengujian kuat tekan pada roster semakin menurun, maka penyerapan air pada roster menjadi meningkat.

\section{Hasil Pengujian Persyaratan Analisis}

Uji Normalitas Kuat Tekan Roster

\begin{tabular}{|c|c|c|c|}
\hline Subjek & $\begin{array}{c}L_{\text {hitung }} \\
\left(L_{0}\right)\end{array}$ & $L_{\text {tabel }}\left(L_{t}\right)$ & Kesimpulan \\
\hline Roster dengan persentase serat ijuk 2\% & 0,3258 & & \\
Roster dengan persentase serat ijuk 4\% & 0,2159 & \multirow{2}{*}{0,4050} & $\begin{array}{c}L_{\text {hitung }}<L_{\text {tabel }} \\
\text { Roster dengan persentase serat ijuk 6\% }\end{array}$ \\
Roster dengan persentase serat ijuk 8\% & 0,2090 & & \\
\hline
\end{tabular}

Hasil Uji Homogenitas Kuat Tekan Roster

\begin{tabular}{|c|c|c|}
\hline$X^{2}{ }_{\text {hitung }}$ & $\mathrm{X}^{2}{ }_{\text {tabel }}$ & Hasil \\
\hline 11,072 & 11,30 & $\mathrm{X}^{2}{ }_{\text {hitung }}<\mathrm{X}^{2}{ }_{\text {tabel }}$ \\
(Data Homogen)
\end{tabular}


Hasil Uji Analisis Varians Kuat tekan Tekan Roster

\begin{tabular}{|l|c|c|c|c|c|}
\hline \multicolumn{1}{|c|}{ Daftar variansi } & $\mathrm{dk}$ & $\mathrm{JK}$ & $\mathrm{KT}$ & $\mathrm{F}_{\text {hitung }}$ & $\mathrm{F}_{\text {tabel }}$ \\
\hline Rata-rata & 1 & 416.02 & 416.02 & & \\
Antar Kelompok & 3 & 48.878 & 16.29 & 65.16 & 5.29 \\
Dalam Kelompok & 16 & 1.015 & 0.063 & & \\
\hline \multicolumn{1}{|c|}{ Total } & 20 & & & & \\
\hline
\end{tabular}

\section{Pengujian Hipotesis}

Untuk mendapatkan hasil pengujian, maka data penelitian dianalisa dengan menggunakan Uji Analisis Varians satu arah dengan taraf signifikan $(\alpha)=$ 0,01 , kriteria pengujian adalah : ditolak $\mathrm{H}_{0}$ jika $F_{\text {hitung }}>\mathrm{F}_{\text {tabel }}$ Rangkuman hasil Uji Analisis Varians dapat dilihat pada tabel berikut ini :

Hasil Uji Analisis Varians Kuat tekan Tekan Roster

\begin{tabular}{|l|c|c|c|c|c|}
\hline \multicolumn{1}{|c|}{ Daftar variansi } & $\mathrm{dk}$ & $\mathrm{JK}$ & $\mathrm{KT}$ & $\mathrm{F}_{\text {hitung }}$ & $\mathrm{F}_{\text {tabel }}$ \\
\hline Rata-rata & 1 & 416.02 & 416.02 & & \\
Antar Kelompok & 3 & 48.878 & 16.29 & 65.16 & 5.29 \\
Dalam Kelompok & 16 & 1.015 & 0.063 & & \\
\hline \multicolumn{1}{|c|}{ Total } & 20 & & & & \\
\hline
\end{tabular}

Dari tabel tersebut di atas dengan dk pembilang 3, dk penyebut 16 dan peluang 0,99 (taraf nyata $\alpha=0,01$ ) didapat $F_{\text {tabel }}=5.29$ dan $F_{\text {hitung }}=65.26$. ternyata $F_{\text {hitung }}>F_{\text {tabel }}$ maka $H_{0}$ ditolak dalam taraf signifikan $(\alpha)=0,01$. (hasil perhitungan dapat dilihat pada lampiran 24 hal. 105). Kesimpulannya adalah terdapat perbedaan antara nilai kuat tekan roster dengan menggunakan bahan tambah serat ijuk sebesar $2 \%, 4 \%, 6 \%$ dan $8 \%$ terhadap berat semen. 


\section{Kesimpulan}

Berdasarkan hasil penelitian maka dapat disimpulkan sebagai berikut :

1. Nilai optimum kuat tekan roster yang menggunakan bahan tambah serat ijuk ternyata masih lebih rendah dari nilai kuat tekan roster kelas BBK 10 Standar Nasional Indonesia 03-1570-1989 (10 N/mm²), hal ini disebabkan karena pemotongan serat ijuk yang terlalu panjang yaitu $3 \mathrm{~cm}$, dan juga dikarenakan pencampuran serat ijuk pada adukan roster yang tidak merata karena pencampuran yang dilakukan secara manual, sedangkan dengan nilai hasil pengujian penyerapan air untuk semua perlakuan pada roster dapat dikatakan termasuk pada mutu I karena kadar airnya masih di bawah $25 \%$.

2. Nilai kuat tekan rata-rata roster yang optimum dicapai oleh kelompok roster pada penggunaan bahan tambah serat ijuk $2 \%$ yaitu sebesar $7.04 \mathrm{~N} / \mathrm{mm}^{2}$. Sedangkan roster pada penggunaan serat ijuk $4 \%$ sebesar $4.71 \mathrm{~N} / \mathrm{mm}^{2}$, roster pada penggunaan serat ijuk $6 \%$ sebesar $3.52 \mathrm{~N} / \mathrm{mm}^{2}$ dan roster pada penggunaan serat ijuk $8 \%$ sebesar $2.98 \mathrm{~N} / \mathrm{mm}^{2}$. Dimana dari keempat perlakuan tersebut tidak memenuhi persyaratan roster Standar Nasional Indonesia 03-1570-1989 dan ke dalam kelas BBK 10 yaitu minimal mempunyai kuat tekan rata-rata sebesar $10 \mathrm{~N} / \mathrm{mm}^{2}$.

3. Semakin tinggi persentase serat ijuk yang diberikan maka penyerapan airnya semakin besar, beratnya semakin ringan dan kuat tekannya semakin menurun.

\section{Implikasi}

Dari hasil penelitian yang telah dilaksanakan, jelas hasilnya telah terbukti bahwa dengan beberapa perlakuan yang diteliti, serat ijuk dapat mempengaruhi kekuatan tekan pada pembuatan roster. Sedangkan untuk pembuatan bata beton selain roster yang menggunakan perbandingan $1 \mathrm{sp}: 6$ Ps sebaiknya diteliti lebih lanjut, karena semakin banyak serat ijuk yang diberikan maka semakin menurun mutunya.

ljuk termasuk dalam bahan yang dapat dicampurkan dengan agregat lain serta dapat menyerap air dalam jumlah tertentu hingga memberikan hasil adukan

Studi Pemanfaatan Serat ljuk Sebagai Bahan Tambah Terhadap Batu Bata Beton Karawang/Roster (Erna Septiandini, Dosen Jurusan Teknik Sipil FT-UNJ) 
yang tidak terlalu cair. Kuat tekan optimal roster hasil penelitian dibandingkan dengan kuat tekan standar SNI kelas BBK 10 lebih rendah, sehingga dapat dikatakan serat ijuk kurang mempunyai pengaruh sebagai bahan tambah pada roster, tetapi baik untuk kuat lentur. Hal ini jika kita implikasikan dengan teori yang ada cukup relevan yaitu penambahan serat organik ijuk pada pembuatan genteng beton dapat meningkatkan kekuatan lentur serta mengurangi sifat regasnya.

\section{Saran}

Berdasarkan proses pelaksanaan dan hasil diperoleh dalam penelitian ini, maka dapat diajukan saran-saran sebagai berikut :

1. Dalam kaitannya dengan pemanfaatan serat ijuk sebagai bahan bangunan, serat ijuk sebaiknya diteliti lebih lanjut dan ukuran potongan serat ijuk disesuaikan dengan kebutuhan.

2. Dalam kaitannya dengan peningkatan pengetahuan mahasiswa Jurusan Teknik Sipil Fakultas Teknik Universitas Negeri Jakarta, hendaknya mahasiswa lebih aktif dalam mencari informasi dan data mengenai hasil-hasil penelitian yang telah ada, agar dapat dilakukan penelitian selanjutnya.

\section{Daftar Pustaka}

Dinas Perindustrian DKI Jakarta, Petunjuk Teknis Proses Pembuatan Bata Beton, (Jakarta : Balai Penelitian Bahan, 1989).

Lesmono, Kus, Studi Analisis Pembuatan Serat Semen Yang Menggunakan Campuran Sabut Kelapa Dan ljuk Terhadap Kuat Lentur Serat semen Standar, (Jakarta : Skripsi IKIP, 1999).

Murdock, L. J., K. M. Brook, Bahan Dan Praktek Beton, (Jakarta : Erlangga, 1999).

Rachmad, Mulyadi, Kuat Tarik Statis dan Daya Serap Netron Pada komposit Orthotropik Resin Polyester-Serat ljuk, (Jakarta, Skripsi UI, 1990)

Pusat Penelitian dan Pengembangan Pemukiman, Persyaratan Umum Bahan Bangunan di Indonesia, (Bandung : Badan Penelitian Dan Pengembangan P.U, 1986).

SK SNI S-04-1989-F, Spesifikasi Air Sebagai Bahan Bangunan, (Bandung : Yayasan LPMB 1989). 
SNI 03-1570-1989, Bata Beton Karawang (Roster), (Jakarta : Dewan Standarisasi Nasional, 1989).

SNI 03-1750-1990, Mutu Dan Cara Uji Agregat Beton, (Jakarta : Departemen Perindustrian, 1990).

SNI 03-1968-1990, Metode Pengujian Tentang Analisa Saringan Agregat Halus dan Kasar, (Jakarta : Departemen Pekerjaan Umum, 1990).

SNI 03-2816-1992, Metode Pengujian Kotoran Organik dalam Pasir Untuk Campuran Mortar Atau Beton, (Jakarta : Departemen Pekerjaan Umum).

Sahrowardi, Studi Perbandingan Kekuatan Tekan Hancur Antara Bata Beton Yang Menggunakan Campuran Tambahan Skaring Dan Ijuk, (Jakarta : Skripsi IKIP, 1992).

Saputra, Ade, ljuk Sebagai Bahan Penambah Pada Campuran Batako Press Terhadap Kuat Tekan Batako, (Jakarta : Skripsi UNJ, 2003).

Sudjana, Metoda Statistika, (Bandung : Tarsito,1996).

Sunanto, Hatta, Aren Budidaya dan Multigunanya, (Bandung : Armico, 1987).

Widardo, Sri Hidayati, Laporan Penelitian Genteng ljuk Sebagai Bahan Bangunan_(Minahasa : Dept. Perindustrian, 1996).

Studi Pemanfaatan Serat ljuk Sebagai Bahan Tambah Terhadap Batu Bata Beton Karawang/Roster (Erna Septiandini, Dosen Jurusan Teknik Sipil FT-UNJ) 